\title{
Effects of dietary coconut oil on apolipoprotein B synthesis and VLDL secretion by calf liver slices
}

\author{
Dominique Gruffat-Mouty $^{1 *}$, Benoît Graulet ${ }^{1}$, Denys Durand ${ }^{1}$, Marie Elisabeth Samson-Bouma ${ }^{2}$ and \\ Dominique Bauchart ${ }^{1}$ \\ ${ }^{1}$ Unité de Recherches sur les Herbivores, Équipe Nutriments et Métabolismes, Institut National de Recherche Agronomique, \\ Centre de Recherches Clermont Ferrand - Theix, 63122 Saint Genès Champanelle, France \\ ${ }^{2}$ INSERM U 327, Faculté de Médecine Xavier Bichat, 16 rue Henri Huchard, BP 416, 75870 Paris Cedex 18, France
}

(Received 31 March 2000 - Revised 18 January 2001 - Accepted 25 January 2001)

\begin{abstract}
Incorporation of coconut oil (CO) rich in lauric acid into the milk diet induces a lipid infiltration of the liver (steatosis) in 1-month-old calves. Among possible steps involved in diet-induced liver steatosis, the ability of the calf liver to synthesize apolipoprotein (Apo) B and to secrete it as part of VLDL particles was investigated. Liver samples were taken from calves fed for $17 \mathrm{~d}$ on a conventional milk replacer containing $\mathrm{CO}(n 5)$ and beef tallow (BT, $n 4)$ as reference. Samples were cut into slices $0.5 \mathrm{~mm}$ thick and subsequently incubated for $12 \mathrm{~h}$ in a medium containing a $\left[{ }^{35} \mathrm{~S}\right]$ methionine- $-\left[{ }^{35} \mathrm{~S}\right]$ cysteine mix and $0.8 \mathrm{mM}$-sodium laurate or oleate, the major fatty acids of $\mathrm{CO}$ and BT diets respectively. Concentrations of total $\left[{ }^{35} \mathrm{~S}\right]$ proteins, $\left[{ }^{35} \mathrm{~S}\right]$ albumin and $\left[{ }^{35} \mathrm{~S}\right] \mathrm{ApoB}$ in liver cells were 2 -fold lower $(P=0.08,0.0004$ and 0.03 respectively) in COthan in BT-fed calves. Although the total amount of proteins secreted (including albumin) was similar in both groups of calves, the amount of VLDL- $\left[{ }^{35} \mathrm{~S}\right]$ Apo secreted was 2-fold lower $(P=$ 0.004) in CO- than in BT-fed calves. These results suggest that a CO-enriched milk diet induces in preruminant calves a lipid infiltration of the liver by decreasing ApoB synthesis, leading to a reduction in secretion of VLDL particles.
\end{abstract}

Liver slices: Coconut oil: Apolipoprotein B: VLDL: Calf

Conventional milk replacers for calves, rich in fat $(\geq 20 \mathrm{~g} /$ $\mathrm{km} \mathrm{DM})$, are consistent with nutritional requirements of suckling calves, leading to a high growth performance of animals and to production of good quality carcasses (Bauchart \& Aurousseau, 1993). Beef tallow (BT) and lard are the most commonly used sources of fat for preruminant calves because of their adequate fatty acid (FA) composition for calf performance, their availability and low cost. However, to avoid any risk of transmission of bovine spongiform encephalopathy to animals and to consumers, the replacement of these animal fats in milk substitutes given to calves by vegetable oils from palm, soyabean, rapeseed and coconut palm has become necessary in the countries of European Union. However, vegetable oils rich in polyunsaturated fatty acids, such as soyabean oil, given as the sole source of FA to calves induced several negative consequences: they impaired animal growth rates (Jenkins \& Kramer, 1986), favoured accumulation of polyunsaturated fatty acids sensitive to peroxidation, induced hypercholesterolaemia (LeplaixCharlat et al. 1996a) and lipid infiltration of the liver (Leplaix-Charlat et al. 1996b) in these animals. In addition, palm oil ingestion favoured the incorporation of palmitic acid in calf tissues: this saturated FA is considered to be atherogenic (Khosla \& Hayes, 1993) and consequently, prejudicial for man's health.

It has been demonstrated that dietary medium-chain FA lead to intensive growth of young preruminant calves (Aurousseau et al. 1983, 1984). Since they are preferentially oxidized by peripheral tissues, medium-chain FA would stimulate proteinogenesis (Aurousseau et al. 1983, 1984; Jenkins et al. 1985) increasing the growth rate by $45 \%$ from birth to $15 \mathrm{~d}$ old. Coconut oil (CO) rich in medium-chain FA (lauric acid and myristic acid, $45 \mathrm{~g}$ and $17 \mathrm{~g} / 100 \mathrm{~g}$ total FA respectively) mixed with BT in the milk diet is therefore recommended for improving growth performance and protein accretion in muscles of calves from birth to the age of 3 weeks (Bauchart \& Aurousseau,

\footnotetext{
Abbreviations: Apo, apolipoprotein; BT, beef tallow; CO, coconut oil; FA, fatty acids; TG, triacylglycerol.

* Corresponding author: Dr Dominique Gruffat-Mouty, fax +33 047362 46 39, email gruffat@clermont.inra.fr
} 
1993). However, after prolonged consumption of mediumchain FA, an accumulation of triacylglycerol (TG) composed of higher FA produced either by elongation of medium-chain FA or by de novo synthesis from acetyl-CoA derived from medium-chain FA oxidation was observed in the liver of rat (Petit et al. 1982) and of preruminant calf (Bauchart et al. 1998; Graulet et al. 1998). When CO was given as the sole source of FA to older calves, it induced TG accumulation in the calf liver (Jenkins et al. 1985; Bauchart et al. 1999) leading to liver steatosis, detrimental to the health and growth performance of the animals. Graulet et al. (2000) demonstrated on liver slices (prepared from liver samples taken from the same calves as those used in the present experiment) that FA esterification into neutral lipids (mainly TG) and their accumulation in hepatic cells were 3 -fold higher in liver slices from CO-fed calves compared with BT-fed calves. This increase was positively correlated a far higher lipid content in the liver of calves fed the CO-rich diet (Bauchart et al. 1998).

Hepatic secretion of VLDL, involved in the blood transport of liver TG, is a complex process requiring the coordinated synthesis of lipids and apolipoprotein (Apo) B followed by their assembly into lipoprotein particles (Gibbons, 1990; Gruffat et al. 1996b). Microsomal TG transfer protein is necessary for lipoprotein assembly, most likely by transferring TG to nascent ApoB when it enters the lumen of the endoplasmic reticulum (Wetterau et al. 1997). In most animal species, hepatic ApoB levels are mainly regulated postranscriptionally by an intracellular degradation process which occurs in the endoplasmic reticulum compartment and, perhaps, in the Golgi compartment (Yao et al. 1997). This mechanism led to the idea that ApoB is synthesized constitutively and in excess in hepatocytes; this results in certain advantages for cells by enabling them to adjust rapidly to the need to secrete TG into the blood circulation without invoking the translation of this enormous protein.

In contrast, it has been proposed in different ruminant species, that the low availability of ApoB limiting its incorporation into VLDL particles might explain the low VLDL output usually observed (Grummer, 1993; Bauchart et al. 1996). Indeed, it has been shown that in highproducing dairy cows during early lactation compared with the dry period, the net decrease of ApoB levels in the liver and in the plasma was correlated with an increase in liver TG content (Marcos et al. 1990; Gruffat et al. 1996a). Similar induction of fatty liver was obtained when ethionine (an inhibitor of protein synthesis) was given to cows, suggesting that Apo availability is a limiting step for VLDL secretion (Ushida et al. 1992).

The objective of the present study was to determine if the lipid infiltration noted in the liver of calves fed a CO-based milk replacer for $17 \mathrm{~d}$ can be explained by a specific regulation in hepatic ApoB synthesis and secretion as part of VLDL particles. For this purpose, we studied the rates of ApoB synthesis and of VLDL secretion in in vitro labelling conditions by incubating liver slices for $12 \mathrm{~h}$ in the presence of $\left[{ }^{35} \mathrm{~S}\right]$ methionine- $\left[{ }^{35} \mathrm{~S}\right]$ cysteine, comparing liver slices from CO- and BT-fed calves. Moreover, to reproduce conditions close to in vivo dietary conditions and to investigate the specific effects of major dietary FA, liver slices were incubated in the presence of lauric acid or oleic acid, which are the main FA of CO (42 g/100 g FA) and BT (38 g/100 g FA) diets respectively.

\section{Materials and methods}

\section{Materials}

Methionine-cysteine-free RPMI-1640 culture medium for liver cells, oleic acid, lauric acid, FA-free bovine serum albumin, L-glutamine, antibiotic-antimycotic mixture, protease inhibitors and bisbenzimidazole (Hoechst 33258) were obtained from Sigma Chemical Co., St Louis, MO, USA. $\left[{ }^{35}\right.$ S $]$ protein labelling mix was obtained from du Pont de Nemours S.A., Les Ulis, France. Organ culture dishes with a centre well were obtained from Falcon, Division of Becton Dickinson, Cockeysville, MD, USA. Centrikon T2060 ultracentrifuge equipped with the TST 41-14 swinging bucket rotor were manufactured by Kontron Analysis Division, Zürich, Switzerland.

\section{Animals and diets}

The experiment was carried out using nine preruminant Holstein-Friesian male calves (7 (SE 3) d old, 50.8 (SE 7.4) $\mathrm{kg}$ body weight). Calves were divided into two groups matched in age and body weight. Each group received a conventional liquid milk replacer containing either $\mathrm{CO}(n 5)$ or BT $(n 4)$. Chemical composition of the milk diets, including the detailed FA composition, is given in Table 1. The experiment consisted of a $17 \mathrm{~d}$ period during which

Table 1. Composition of the experimental milk diets

\begin{tabular}{lcc}
\hline Ingredient & $\begin{array}{c}\text { Beef tallow-based } \\
\text { diet }\end{array}$ & $\begin{array}{c}\text { Coconut oil-based } \\
\text { diet }\end{array}$ \\
\hline Spray-dried skimmed & 716 & 716 \\
milk powder (g/kg DM) & & - \\
Beef tallow (g/kg DM) & 224 & 224 \\
Coconut oil (g/kg DM) & - & 50 \\
Corn starch (g/kg DM) & 50 & 10 \\
Vitamin and mineral & 10 & \\
mixture (g/kg DM) & & \\
Fatty acids (g/100 g & & \\
total fatty acids) & & $0 \cdot 6$ \\
c8:0 & $0 \cdot 1$ & $4 \cdot 0$ \\
c10:0 & $0 \cdot 1$ & $42 \cdot 4$ \\
c12:0 & $2 \cdot 9$ & $17 \cdot 9$ \\
c14:0 & $4 \cdot 2$ & $12 \cdot 8$ \\
c16:0 & $22 \cdot 3$ & 0.5 \\
c16:1 $n-7$ & $2 \cdot 4$ & $5 \cdot 0$ \\
c18:0 & $19 \cdot 2$ & $12 \cdot 1$ \\
c18:1 $n-9$ & $37 \cdot 8$ & $3 \cdot 0$ \\
c18:2 $n-6$ & $2 \cdot 4$ & $0 \cdot 3$ \\
c18:3 $n-3$ & $0 \cdot 4$ & $0 \cdot 3$ \\
$\sum \mathrm{C}_{20}$ & $0 \cdot 8$ & $0 \cdot 1$ \\
$\sum \mathrm{C}_{22}$ & $0 \cdot 2$ & $0 \cdot 9$ \\
Others & $4 \cdot 0$ & \\
\hline
\end{tabular}

* The vitamin and mineral mixture contained (per kg mixture): $\mathrm{MgSO}_{4} 0.15 \mathrm{~g}$, $\mathrm{MgO} 0.30 \mathrm{~g}, \mathrm{FeSO}_{4} 8 \mathrm{mg}, \mathrm{CuSO}_{4} 10 \mathrm{mg}, \mathrm{ZnSO}_{4} 80 \mathrm{mg}, \mathrm{MnSO}_{4} 48 \mathrm{mg}$, $\mathrm{COSO}_{4} 0.6 \mathrm{mg}, \mathrm{Cal}_{2} 0.18 \mathrm{mg}, \mathrm{Na}_{2} \mathrm{SeO}_{3} 0.15 \mathrm{mg}$, retinol $8.6 \mathrm{mg}$, cholecalciferol $125 \mu \mathrm{g}, \alpha$-tocopherol $50 \mathrm{mg}$, thiamine $5 \mathrm{mg}$, riboflavin $10 \mathrm{mg}$, panthothenic acid $25 \mathrm{mg}$, niacin $40 \mathrm{mg}$, cyanocobalamin $0.08 \mathrm{mg}$, pyridoxine $4 \mathrm{mg}$, menadione $2.5 \mathrm{mg}$, ascorbic acid $100 \mathrm{mg}$, biotin $0.1 \mathrm{mg}$, folic acid $1.2 \mathrm{mg}$, methionine $0.6 \mathrm{~g}$, lysine chloride $0.8 \mathrm{~g}$, choline $0.8 \mathrm{~g}$, virginiamycin $0.05 \mathrm{~g}$, sorbitol $3 \mathrm{~g}$ (Celtic Langlois, St. Jacques de la Lande, France). 
calves were fed one of the two respective diets according to the recommendations of Toullec (1978). In these dietary conditions, weight gains $(\mathrm{kg} / \mathrm{d}$ ) were 0.64 (SE 0.29) and 0.97 (SE 0.56) for the first week of experiment and 0.93 (SE 0.27) and $0 \cdot 86(\mathrm{SE} 0 \cdot 10)$ for the last $10 \mathrm{~d}$ of experiment for $\mathrm{CO}$ - and BT-fed calves respectively. Liquid milk replacer was bucketfed in two equal portions per $\mathrm{d}$ at $8 \mathrm{~h}$ and $16 \mathrm{~h}$. Calves were housed on a litter of wood shavings in an air-conditioned room $\left(20^{\circ} \mathrm{C}\right.$ mean temperature; $80 \%$ relative humidity).

\section{Liver slice incubation and analytical methods}

Liver slice incubation. Liver tissue samples $(1 \mathrm{~g})$ were taken by puncture biopsy from an homogeneous and representative region of tissue $7 \mathrm{~h}$ after the morning meal (i.e. at peak of lipid absorption) under total anaesthesia (isoflurane, $2 \%$ in $\mathrm{O}_{2}, 0.5$ litres/min) just before slaughter of the calf. Tissue samples, placed immediately into an icecold salt solution containing $0.4 \mathrm{~g} \mathrm{KCl} / 1,6 \mathrm{~g} \mathrm{NaCl} / 1,0.8 \mathrm{~g}$ $\mathrm{NaHPO}_{4} / \mathrm{l}(\mathrm{pH} 7.4)$ and $2 \mathrm{~g}$ D-glucose/l, were used for metabolic assays within $30 \mathrm{~min}$.

Liver samples were metabolically labelled according to the method initially developed in human subjects by Bouma et al. (1990) and adapted to bovine liver by Gruffat-Mouty et al. (1999). Briefly, liver samples provided from one biopsy were sliced to a thickness of about $0.5 \mathrm{~mm}$ and five slices were placed on a stainlesssteel grid in an organ culture dish. The culture medium consisted of methionine-cysteine-free RPMI-1640 containing $300 \mathrm{mg} \mathrm{L}$-glutamine/l, an antibiotic-antimycotic mixture $(100 \mathrm{U}$ penicillin $/ \mathrm{ml}, 0 \cdot 1 \mathrm{mg}$ streptomycin $/ \mathrm{ml}$ and $0.25 \mu \mathrm{g}$ amphotericin $\mathrm{B} / \mathrm{ml}),\left[{ }^{35} \mathrm{~S}\right]$ protein labelling mix (composed of $\left[{ }^{35} \mathrm{~S}\right]$ methionine $(730 \mathrm{~g} / \mathrm{l})$ and $\left[{ }^{35} \mathrm{~S}\right]$ cysteine $\left.(220 \mathrm{~g} / \mathrm{l}), 43.5 \times 10^{6} \mathrm{MBq} / \mathrm{mmol}, 5.5 \mathrm{MBq} / \mathrm{ml}\right)$ and $0.8 \mathrm{mM}$ sodium salt of lauric acid or of oleic acid complexed to FA-free bovine serum albumin in a 4:1 molar ratio. The effects of sodium laurate or sodium oleate were tested on liver slices prepared from liver samples taken from calves fed CO and BT. Kinetic experiments (3, 6, 9 and $12 \mathrm{~h}$ ) were performed to verify the correct viability of liver slices. At the end of incubation $(12 \mathrm{~h})$, media were collected and supplemented with a protease inhibitor mixture (final concentrations: $0.31 \mu \mathrm{g}$ pepstatin $/ \mathrm{ml}$, $1.56 \mu \mathrm{g}$ leupeptin/ml, $1.56 \mu \mathrm{g}$ antipain/ml, $0.31 \mu \mathrm{g}$ aprotinin $/ \mathrm{ml}, \quad 31.2 \mu \mathrm{g}$ trypsin-chymotrypsin inhibitor $/ \mathrm{ml}$, 0.31 mM-phenylmethyl sulfonyl fluoride). Liver slices were washed twice with $1 \mathrm{ml}$ ice-cold salt solution containing $0.4 \mathrm{~g} \mathrm{KCl} / \mathrm{l}, 6 \mathrm{~g} \mathrm{NaCl} / \mathrm{l}, 0.8 \mathrm{~g} \mathrm{NaHPO}_{4} / \mathrm{l}(\mathrm{pH}$ 7.4) and $2 \mathrm{~g}$ D-glucose/l and washing solutions were pooled with corresponding media. Liver slices were homogenized with a Dounce apparatus in $2 \mathrm{ml} 25 \mathrm{mM}-$ Tris- $\mathrm{HCl}(\mathrm{pH} 8.0), 50 \mathrm{mM}-\mathrm{NaCl}$ containing the same protease inhibitor mixture as described earlier.

Total newly synthesized and secreted proteins. Total proteins from cell homogenates or media were isolated by precipitation with ice-cold TCA as previously described (Gruffat-Mouty et al. 1999) and counted for radioactivity in a $\beta$-scintillation counter.

Newly synthesized and secreted apolipoprotein $B$ and albumin. ApoB and albumin were separated by electrophoresis on continuous polyacrylamide gradient gel slabs from 2.5 to $7.5 \%$ in denaturing conditions and isolated from Coomassie blue-stained gels as previously described (Gruffat-Mouty et al. 1999).

$V L D L$ isolation. Isolation of VLDL secreted by liver slices was performed by ultracentrifugation of $3 \mathrm{ml}$ medium at $100000 \mathrm{~g}$ for $16 \mathrm{~h}$ at $15^{\circ} \mathrm{C}$ (Gruffat-Mouty et al. 1999). Portions of medium were supplemented with purified calf VLDL ( $0.3 \mathrm{mg}$ VLDL-TG/tube) to carry away $\left[{ }^{35} \mathrm{~S}\right]$-labelled VLDL during ultracentrifugation and with an excess of bovine serum albumin (50 mg/tube) to clean VLDL particles from $\left[{ }^{35} \mathrm{~S}\right]$ albumin. After isolation of VLDL from medium, the amount of labelled VLDL-Apo were directly measured by counting the VLDL fractions because the amount of VLDL secreted was too low to allow ApoB identification by staining with Coomassie blue polyacrylamide gels, meaning that it was impossible to measure radioactivity of $\mathrm{ApoB}$ in aliquots used for electrophoresis.

Hepatic DNA. Determination of DNA content of liver cells was performed according to the method described by Labarca \& Paigen (1980). Briefly, total DNA was determined by fluorimetric analysis $(356 \mathrm{~nm}$ and $458 \mathrm{~nm}$ for excitation and emission wavelengths respectively) using calf thymus DNA $(5 \mu \mathrm{g} / \mathrm{ml})$ as a DNA reference. The number of hepatic cells in each liver sample was calculated from DNA values considering that $10^{6}$ hepatic cells contained $6.4 \mu \mathrm{g}$ DNA (Sober, 1970).

Statistical analysis. All values are expressed as the mean values with their standard errors for independent experiments.

Global responses for kinetics (3, 6, 9 and $12 \mathrm{~h}$ ) of each group were analysed by repeated-measures ANOVA using the SAS program (version 6, 1987; Statistical Analysis Systems Inc., Cary, NC, USA) with time of liver slice incubation as the variable with repeated measures. Sources of variation in the model included diet, FA, and time.

Values obtained after $12 \mathrm{~h}$ incubation were analysed by ANOVA using the GLM procedure of SAS (Version 6, 1987; Statistical Analysis Systems Inc.). The effects tested in the model included dietary FA treatment (CO or BT, presented as Diet), calf tested within dietary FA treatment, FA tested (laurate or oleate, presented as FA) in the medium and the interaction between dietary FA treatment and tested FA (presented as Diet $\times$ FA). The diet factor was tested against calves within groups. The residual mean square was used as the error term for the other effects.

Comparisons among FA (laurate $v$. oleate) within an animal of the dietary group (CO or BT) were analysed using the Student's $t$ test for paired data. Comparisons of the mean values between calves of the two dietary groups (CO or BT) were made using Student's $t$ test for unpaired data.

\section{Results}

To determine hepatic protein metabolism, liver slices from calves fed the CO- or the BT-enriched milk diet were incubated for $12 \mathrm{~h}$ in a medium containing $\left[{ }^{35} \mathrm{~S}\right]$ methionine- $\left[{ }^{35} \mathrm{~S}\right]$ cysteine in the presence of $0.8 \mathrm{mM}$-sodium laurate or $0.8 \mathrm{mM}$-sodium oleate, the major FA provided by $\mathrm{CO}$ and $\mathrm{BT}$ diets respectively. 

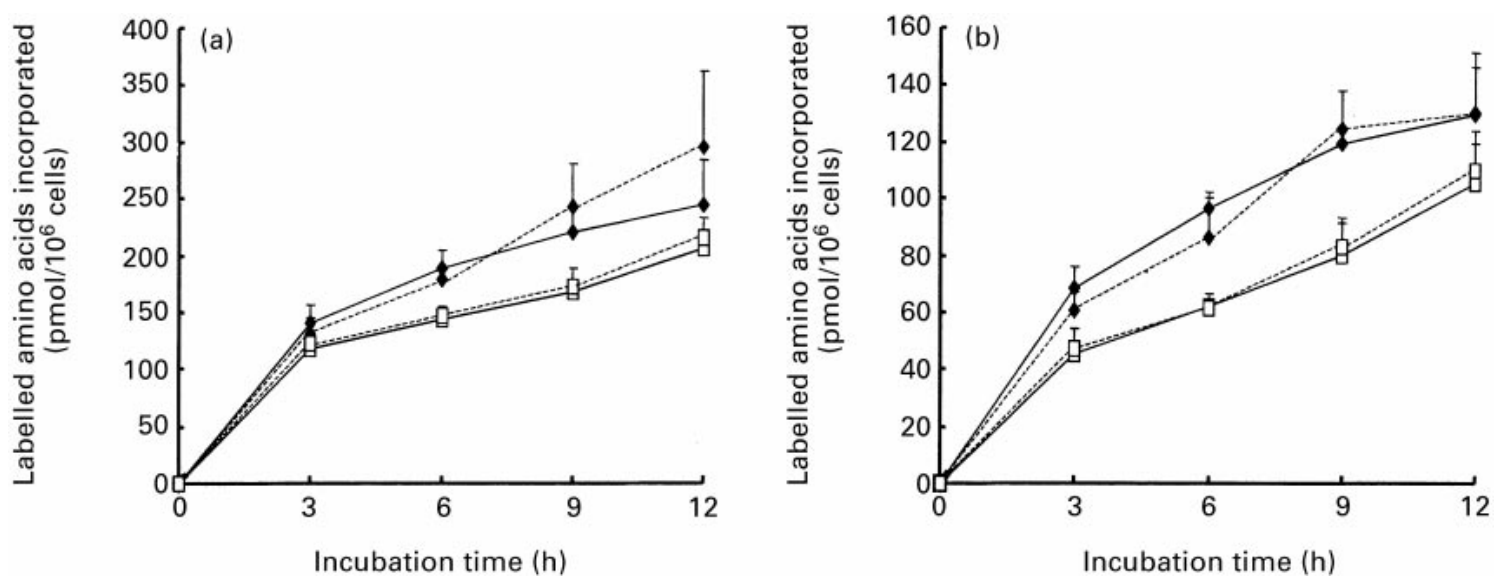

Fig. 1. Time-course of $\left[{ }^{35} \mathrm{~S}\right]$-labelled amino acid incorporation into cells (a) and into total proteins (b) in calf liver slices. Liver slices prepared from liver samples taken from calves fed beef tallow $(\bullet)$ or coconut oil $(\square)$ were incubated in the presence of $\left[{ }^{35} S\right]$ methionine-[ $\left.{ }^{35} S\right]$ cysteine $\left(43.5 \times 10^{6} \mathrm{MBq} / \mathrm{mmol} ; 5.5 \mathrm{MBg} / \mathrm{ml}\right)$ and $0.8 \mathrm{mM}$-oleate $(-)$ or $0.8 \mathrm{mM}$-laurate $(---)$ for $12 \mathrm{~h}$. Incorporation of [ $\left.{ }^{35} \mathrm{~S}\right]$-labelled amino acids into cells corresponded to total radioactivity in cells plus $\left[{ }^{35} \mathrm{~S}\right.$ ]-labelled TCA-precipitable proteins in the medium. Incorporation of [ $\left.{ }^{35} \mathrm{~S}\right]-$ labelled amino acids into total proteins corresponded to radioactivity into TCA-precipitable cellular proteins plus medium proteins. For details of diets and procedures, see p. 14. Mean values in lines for liver slices of beef tallow-fed calves were significantly different from those of liver slices of coconut oil-fed calves $\left({ }^{+} P=0.03\right.$, repeated-measures ANOVA).

\section{Incorporation of $\left[{ }^{35}\right.$ S Jmethionine- $\left[{ }^{35}\right.$ S $]$ cysteine}

Time course incorporation of $\left[{ }^{35} \mathrm{~S}\right]$ methionine- $\left[{ }^{35} \mathrm{~S}\right]-$ cysteine by liver cells (Fig. 1(a)), corresponding to total radioactivity present in both cells and $\left.{ }^{35} \mathrm{~S}\right]$-labelled medium proteins, increased with time $(P=0.0001)$, which indicated a correct functional viability of liver slices during the incubation period. However, the rate of incorporation of $\left[{ }^{35} \mathrm{~S}\right]$ methionine- $\left[{ }^{35} \mathrm{~S}\right]$ cysteine tended to be slightly lower $(P=0.09)$ for the CO than for the BT liver slices in the presence of both laurate or oleate in medium.

\section{Total newly synthesized and secreted proteins}

The amounts of $\left[{ }^{35} \mathrm{~S}\right]$-labelled proteins synthesized and secreted (Fig. 1(b)) were significantly lower $(-40--50 \%$ between 3 and $9 \mathrm{~h},-20 \%$ after $12 \mathrm{~h}$ labelling, $P=0.03$ ) in the $\mathrm{CO}$ than in the BT liver slices without significant effect of laurate or oleate added in the medium.

Cell contents of $\left[{ }^{35} \mathrm{~S}\right]$-labelled proteins (Table 2) tended to be 1.5-fold lower $(P=0.08)$ in the $\mathrm{CO}$ group (54.4-62.6 pmol labelled amino acids incorporated $/ 10^{6}$ cells per $12 \mathrm{~h}$ ) than in the BT group (90.55-88.74 pmol labelled amino acids incorporated $/ 10^{6}$ cells per $12 \mathrm{~h}$ ), but no differences were observed in the amount of $\left[{ }^{35} \mathrm{~S}\right]$-labelled proteins secreted by liver slices (Table 2) whatever the FA added to the medium. This indicated that liver slices of $\mathrm{CO}$ group secreted more pmol labelled proteins per pmol cell proteins than those of the BT group (secreted proteins: intracellular proteins ratios 0.83 and 0.45 for $\mathrm{CO}$ and $\mathrm{BT}$ group respectively).

Table 2. Incorporation of $\left[{ }^{35} \mathrm{~S}\right]$-labelled amino acids (pmol labelled amino acid incorporated $/ 10^{6}$ cells per $12 \mathrm{~h}$ ) into total proteins, albumin, apolipoprotein (Apo) B and VLDL-Apo in cells and the medium of incubation of liver slices from calves given the beef tallow- (BT) or coconut oil(CO) based diets

\begin{tabular}{|c|c|c|c|c|c|c|c|}
\hline \multirow[b]{2}{*}{ Diet } & \multirow[b]{2}{*}{ FA tested } & \multicolumn{2}{|c|}{ Total proteins } & \multicolumn{2}{|c|}{ Albumin } & \multirow{2}{*}{$\frac{\text { ApoB-100 }}{\text { Cell }}$} & \multirow{2}{*}{$\frac{\text { VLDL-Apo }}{\text { Medium }}$} \\
\hline & & Cell & Medium & Cell & Medium & & \\
\hline \multirow[t]{2}{*}{$\mathrm{BT}(n 4)$} & Oleate & 90.5 & $39 \cdot 1$ & $4.82^{a}$ & $15 \cdot 36$ & $0.415^{\mathrm{c}}$ & $0.0072^{c}$ \\
\hline & Laurate & 88.7 & 41.4 & $4 \cdot 25^{a}$ & $16 \cdot 96$ & $0.422^{\mathrm{c}, \mathrm{d}}$ & $0.0071^{c}$ \\
\hline \multirow[t]{2}{*}{$\mathrm{CO}(n 5)$} & Oleate & 54.4 & 51.0 & $1.70^{\mathrm{b}}$ & 11.09 & $0 \cdot 170^{d}$ & $0.0025^{d}$ \\
\hline & Laurate & $62 \cdot 6$ & 46.7 & $1 \cdot 74^{\mathrm{b}}$ & 8.29 & $0.224^{c, d}$ & $0.0044^{e}$ \\
\hline \multicolumn{8}{|l|}{ SED* } \\
\hline Between animals & & 28.04 & $9 \cdot 96$ & 0.823 & $6 \cdot 57$ & 0.147 & 0.0015 \\
\hline Within animals & & 11.75 & 9.07 & 0.434 & 5.09 & 0.074 & 0.0009 \\
\hline \multicolumn{8}{|l|}{ Statistical effects of: } \\
\hline Diet & & 0.0827 & 0.1613 & 0.0004 & 0.1174 & 0.0301 & 0.0041 \\
\hline FA & & 0.6367 & 0.8469 & 0.2965 & 0.8368 & 0.4895 & 0.1887 \\
\hline Diet $\times F A$ & & 0.4651 & 0.5392 & 0.2479 & 0.4587 & 0.5897 & 0.1637 \\
\hline
\end{tabular}

FA, Fatty acid.

a,b Mean values within a column with unlike superscripts were significantly different: $P<0.002$. (Student's $t$ test).

$\mathrm{c}, \mathrm{d}, \mathrm{e}$ Mean values within a column with unlike superscripts were significantly different: $P<0.05$ (Student's $t$ test).

${ }^{*} \mathrm{SED}=\sqrt{\text { mean square/total number of observations. }}$ 


\section{Newly synthesized and secreted albumin}

As for total hepatic proteins, the incorporation of $\left[{ }^{35} \mathrm{~S}\right]$ labelled amino acids into albumin synthesized and secreted was significantly lower $(-81.4 \%, P=0.045)$ in the $\mathrm{CO}$ than in the BT group (Table 2) without any effect of the FA added to the medium. Cellular $\left[{ }^{35} \mathrm{~S}\right]$ albumin content (Table 2) was 2.7 -fold lower $(P=0.0004)$ in the $\mathrm{CO}$ $\left(1.7-1.74 \mathrm{pmol}\right.$ labelled amino acids incorporated $/ 10^{6}$ cells per $12 \mathrm{~h})$ than in the BT $(4.82-4.25$ pmol labelled amino acids incorporated $/ 10^{6}$ cells per $12 \mathrm{~h}$ ) liver slices without any significant difference in amounts of $\left[{ }^{35} \mathrm{~S}\right]$ albumin secreted (Table 2) whatever the FA added to the medium. These results showed that liver slices of $\mathrm{CO}$ group secreted more pmol albumin per pmol cell albumin than those of the BT group (secreted albumin:intracellular albumin ratios 5.63 and 3.56 for $\mathrm{CO}$ and BT group respectively).

Since the amount of $\left[{ }^{35} \mathrm{~S}\right]$-labelled amino acids incorporated into total proteins differed between the two groups, the level of radioactivity incorporated into cellular and secreted albumin was expressed as the percentage of the radioactivity incorporated into total proteins. Table 3 shows that the amount of radioactivity incorporated into cell albumin was about 2-fold lower $(P=0.0009)$ in the $\mathrm{CO}$ $(1.61-1.59 \%$ total protein radioactivity) than in the BT (3.83-3.4\% total protein radioactivity) liver slices without any significant difference in the amount of $\left[{ }^{35} \mathrm{~S}\right]$ albumin secreted, whatever the FA present in the medium.

\section{Newly synthesized apolipoprotein B and VLDL secretion}

The amount of intracellular $\left[{ }^{35} \mathrm{~S}\right] \mathrm{ApoB}$ (Table 2) was $2 \cdot 1$ fold lower $(P=0.03)$ in the $\mathrm{CO}(0.17-0.22$ pmol labelled amino acids incorporated $/ 10^{6}$ cells per $12 \mathrm{~h}$ ) than in the BT (0.41-0.42 pmol labelled amino acids incorporated $/ 10^{6}$ cells per $12 \mathrm{~h}$ ) liver slices but the addition of sodium oleate or laurate to the liver slice medium had no specific effect. Newly synthesized ApoB represented 0.19 and 0.34\% $(P=0.087)$ total $\left[{ }^{35} \mathrm{~S}\right]$-labelled proteins for the $\mathrm{CO}$ and the BT liver slices respectively (Table 3 ).
Amounts of total $\left[{ }^{35} \mathrm{~S}\right]$-labelled VLDL-Apo (Table 2) secreted in the medium were 1.9-fold lower $(P=0.0041)$ with the CO (0.0025-0.0044 pmol labelled amino acids incorporated $/ 10^{6}$ cells per $\left.12 \mathrm{~h}\right)$ than with the BT $(0.0072-$ 0.0071 pmol labelled amino acids incorporated $/ 10^{6}$ cells per $12 \mathrm{~h}$ ) liver slices but were not affected by sodium oleate or laurate added to the medium. The level of radioactivity incorporated into Apo of VLDL particles was expressed as \% radioactivity incorporated into total proteins (Table 3$)$. These values were very low (0.0037 and $0.0058 \%$ for the $\mathrm{CO}$ and the $\mathrm{BT}$ groups respectively) but were significantly 1.6 -fold lower $(P=0.064)$ in the CO than in the BT group without effect of laurate or oleate added to the medium.

\section{Discussion}

In the present study, the capacity of calf liver to synthesize ApoB and to secrete VLDL-Apo was investigated using the method based on incubation of liver slices from calves fed the $\mathrm{CO}$ - or the BT-enriched diets to determine possible limiting steps involved in the $\mathrm{CO}$-induced liver steatosis. Accumulation of TG in the liver of calves fed the $\mathrm{CO}$ diet is difficult to analyse. Indeed, these dietary conditions can either alter VLDL-Apo secretion causing TG accumulation in the liver or stimulate TG storage in cytosol which in turn impairs VLDL-Apo secretion. The present in vitro measurement of ApoB-containing-lipoprotein synthesis and secretion was performed under hepatic steatosis, thus leading to a possible altered ApoB metabolism in the liver. However, the lower ability of $\mathrm{CO}$ liver slices to secrete VLDL-Apo is inconsistent with the fact that more pmol protein or albumin per pmol cell protein or albumin were secreted by these liver slices. These results clearly indicated that secretion of VLDL-Apo was regulated by a mechanism different from that for total proteins or albumin. This might be the result of a low availability of intracellular ApoB for VLDL secretion. Indeed, liver slices of calves fed $\mathrm{CO}$ diet synthesized about 2-fold less protein, including

Table 3. Amounts (expressed as \% radioactivity incorporated into total proteins) of albumin, apolipoprotein (Apo) $\mathrm{B}$, and VLDL-Apo present in cells and the medium of incubation of liver slices from calves given the beef tallow(BT) or coconut oil- (CO) based diets

\begin{tabular}{|c|c|c|c|c|c|}
\hline \multirow[b]{2}{*}{ Diet } & \multirow[b]{2}{*}{ FA tested } & \multicolumn{2}{|c|}{ Albumin } & \multirow{2}{*}{$\frac{\text { ApoB-100 }}{\text { Cell }}$} & \multirow{2}{*}{$\frac{\text { VLDL-Apo }}{\text { Medium }}$} \\
\hline & & Cell & Medium & & \\
\hline $\mathrm{BT}(n 4)$ & $\begin{array}{l}\text { Oleate } \\
\text { Laurate }\end{array}$ & $\begin{array}{l}3 \cdot 83^{a} \\
3 \cdot 40^{a}\end{array}$ & $\begin{array}{l}11 \cdot 5 \\
12 \cdot 8\end{array}$ & $\begin{array}{l}0.33^{c} \\
0.35^{c}\end{array}$ & $\begin{array}{l}0.0060^{c} \\
0.0056^{c}\end{array}$ \\
\hline $\mathrm{CO}(n 5)$ & $\begin{array}{l}\text { Oleate } \\
\text { Laurate }\end{array}$ & $\begin{array}{l}1 \cdot 61^{\mathrm{b}} \\
1.59^{\mathrm{b}}\end{array}$ & $\begin{array}{r}10 \cdot 3 \\
8 \cdot 1\end{array}$ & $\begin{array}{l}0 \cdot 17^{d} \\
0 \cdot 21^{c, d}\end{array}$ & $\begin{array}{l}0.0031^{d} \\
0.0043^{c, d}\end{array}$ \\
\hline SED* & & & & & \\
\hline $\begin{array}{l}\text { Between animals } \\
\text { Within animals }\end{array}$ & & $\begin{array}{l}0.2561 \\
0.1161\end{array}$ & $\begin{array}{l}1 \cdot 817 \\
0.777\end{array}$ & $\begin{array}{l}0.0515 \\
0.0323\end{array}$ & $\begin{array}{l}0.00071 \\
0.00047\end{array}$ \\
\hline $\begin{array}{l}\text { Statistical effects of: } \\
\text { Diet } \\
\text { FA } \\
\text { Diet } \times \text { FA }\end{array}$ & & $\begin{array}{l}0.0009 \\
0.2192 \\
0.2506\end{array}$ & $\begin{array}{l}0.2934 \\
0.7089 \\
0.1673\end{array}$ & $\begin{array}{l}0.0865 \\
0.5456 \\
0.8876\end{array}$ & $\begin{array}{l}0.0637 \\
0.3719 \\
0.1778\end{array}$ \\
\hline
\end{tabular}

FA, Fatty acid.

a,b Mean values within a column with unlike superscripts were significantly different: $P<0.005$ (Student's $t$ test)

${ }^{\mathrm{c}, \mathrm{d}, \mathrm{e}}$ Mean values within a column with unlike superscripts were significantly different: $P<0.05$ (Student's $t$ test)

${ }^{*} \mathrm{SED}=\sqrt{\text { mean square/total number of observations. }}$ 
albumin and ApoB, than liver slices from the BT diet calves.

The availability of newly synthesized molecules of apoB in hepatocytes plays a major role in determining the capacity of these hepatocytes to assemble and secrete VLDL (Gibbons, 1990; Gruffat et al. 1996b). Several studies using rodent liver or HepG2 cells as models of hepatocytes have demonstrated that synthesis and secretion of hepatic ApoB were regulated both by nutritional and hormonal factors (Adeli et al. 1995). It is generally admitted that these regulating factors concern mainly the intracellular degradation of the newly synthesized molecules of ApoB (Yao et al. 1997). However, Yasuhara et al. (1991) have shown that fatty liver development in the musk shrew (Suncus murinus) was linked to an altered synthesis of ApoB in the liver. Moreover, it has been demonstrated already in high-yielding dairy cows in negative energy balance during the early lactation that accumulation of TG in the liver is associated with a decrease in the hepatic ApoB content (Grummer, 1993; Gruffat et al. 1996a). Reid \& Collins (1980) suggested, in cows with severe steatosis, that the protein synthesis defect could result from alterations of ultrastructural characteristics of hepatocytes, including mitochondrial damage and decreased volume of rough endoplasmic reticulum. In the present study, calf liver cells developed only a mild steatosis (Bauchart et al. 1999) and, therefore, were able to compensate this metabolic abnormality both by increasing the rate of protein secretion and by maintaining a constant oncotic pressure in the extracellular medium. However, it can not be excluded that the 2-fold decrease of ApoB level in the liver slices of $\mathrm{CO}$ calves led to a lower availability of ApoB for production of VLDL, leading to a 2-fold lower amount of VLDL-Apo secreted in the medium.

Other limiting factors might be involved in the regulation of VLDL-Apo secretion in CO liver slices, such as a defect in mechanisms of VLDL particle assembly, and/or of VLDL secretion.

First, there is the microsomal TG transfer protein, which was an essential factor in the VLDL assembly (Wetterau et al.1997). In rat, microsomal TG transfer protein did not appear to be a regulatory target in the short to medium term (Brett et al. 1995). On the other hand, long-term dietary studies in the hamster have revealed changes in microsomal TG transfer protein mRNA in the liver according to fat sources (Bennett et al. 1995). However, in the calves fed the CO-based diet, microsomal TG transfer protein did not appear to be a major limiting factor for hepatic TG export since it was expressed in the liver to the same extent as in calves fed the BT-based diet (B Graulet, D Mouty, D Durand and D Bauchart, unpublished results).

Another possible limiting factor for VLDL secretion could be the new TG synthesized from exogenous FA, which are poor direct precursors for VLDL synthesis. They are first stored in hepatocellular cytosolic droplets (Gibbons \& Wiggins, 1995), from which they are mobilized via two successive processes of lipolysis and re-esterification into TG (Gibbons \& Wiggins, 1995; Yang et al. 1995). It is possible that these metabolic processes regulate the effective availability of TG at the site of VLDL assembly. A lipolytic enzyme, TG hydrolase, recently purified from pig liver and characterized (Lehner \& Verger, 1997), has been proposed as a regulatory factor involved in the hepatic TG metabolism. However, this enzyme was not expressed in rat (Lehner et al. 1999) nor in bovine (D Gruffat-Mouty, S Pomel, D Durand and D Bauchart, unpublished results) before weaning, suggesting that another lipolytic system involved in processes of lipolysis and re-esterification of FA into TG was implicated in sucking animals.

The respective effects of $\mathrm{CO}$ and $\mathrm{BT}$ diets on protein and ApoB synthesis and VLDL-Apo secretion determined in liver slices were not reproduced when oleic acid or lauric acid was added to the medium. Graulet et al. (2000) showed in these same $\mathrm{CO}$ and BT liver slices that laurate was preferentially oxidized (into $\mathrm{CO}_{2}$ ) rather than esterified into $\mathrm{TG}$, whereas the $\mathrm{CO}$ diet reduced the oxidative capacity of the liver. This discrepancy might be explained by the period of incubation $(12 \mathrm{~h})$, too short to induce similar metabolic effects as in the liver in vivo following 19 d CO feeding. Moreover, smaller differences exist for the other main saturated FA (myristic, palmitic and stearic acids) in the composition of CO- and BT-enriched milk diets, which makes the comparison of effects between natural diets and synthetic diets very difficult.

In conclusion, dietary $\mathrm{CO}$ incorporated as the sole source of FA in the milk diet of calves appeared to interact with hepatic lipid metabolism. Indeed, it induced an hepatic TG accumulation leading to a decrease in total protein content (including a decrease in hepatic albumin and ApoB contents). However, lipid infiltration appeared to be insufficient to inhibit secretory processes allowing normal amounts of proteins in the extracellular medium. Finally, the lower rate of hepatic secretion of VLDL as compared with the rate of hepatic protein secretion rather suggests a specific effect on ApoB production leading to its lower availability for TG secretion as part of VLDL particles.

\section{Acknowledgements}

We thank C. Leoty and R. Souchet for calf management, J. Lefaivre for surgical preparation and F. Duboisset, C. Legay and M. Martinaud for technical assistance.

\section{References}

Adeli K, Mohammadi A \& Macri J (1995) Regulation of apolipoprotein B biogenesis in human hepatocytes: posttranscriptional control mechanisms that determine the hepatic production of apolipoprotein B-containing lipoproteins. Clinical Biochemistry 28, 123-130.

Aurousseau B, Thivend P \& Vermorel M (1984) Influence du remplacement d'une partie du suif d'un aliment d'allaitement par de la tricaproïne ou de la tricapryline en association de l'huile de coprah sur la croissance du jeune veau préruminant (Effects on calf growth of substituting tricaproin or tricaprylin in association with coconut oil for a part of the tallow in a milk replacer for the preruminant calf). Annales de Zootechnie 33, 219-234.

Aurousseau B, Vermorel M \& Bouvier JC (1983) Influence du remplacement d'une partie du suif d'un aliment d'allaitement par de la tricaproïne ou de l'huile de coprah sur l'utilisation de l'énergie et de l'azote par le veau préruminant (Effects on energy and nitrogen balances of substituting tricaproin or 
coconut oil for a part of the tallow in a milk replacer for the preruminant calf). Reproduction Nutrition Développement 35 , 167-178.

Bauchart D \& Aurousseau B (1993) Digestion et métabolisme des lipides chez le veau de boucherie; conséquences sur la composition en lipides des tissus (Lipid digestion and metabolism in the veal calf; effects on the composition of tissue lipids). Viandes et Productions Carnées 14, 172-182.

Bauchart D, Durand D \& Gruffat D (1996) Lipid absorption and hepatic metabolism in ruminants. Proceedings of the Nutrition Society 55, 39-47.

Bauchart D, Durand D, Gruffat-Mouty D, Piot C, Graulet B, Chilliard Y \& Hocquette JF (1999) Transport sanguin et métabolisme tissulaire des lipides chez le veau de boucherie (Blood transport and tissue metabolism of lipids in the preruminant calf). INRA Productions Animales 12, 273-285.

Bauchart D, Durand D, Picherit C, Graulet B \& Gruffat D (1998) Effects of dietary coconut oil on blood transport and in vivo hepatic metabolism of fatty acids in the preruminant calf. Reproduction Nutrition Développement 38, 203.

Bennett AJ, Billett MA, Salter AM \& White DA (1995) Regulation of hamster hepatic triglyceride transfer protein mRNA levels by dietary fats. Biochemical and Biophysical Research Communications 212, 473-478.

Bouma ME, Beucler I, Pessah M, Heinzmann C, Lusis AJ, Naim HY, Ducastelle T, Leluyer B, Schmitz J, Infante R \& Aggerbeck LP (1990) Description of two different patients with abetalipoproteinemia: synthesis of a normal-sized apolipoprotein B-48 in intestinal organ culture. Journal of Lipid Research 31, 1-15.

Brett DJ, Pease RJ, Scott J \& Gibbons GF (1995) Microsomal triglyceride transfer protein activity remains unchanged in rat livers under conditions of altered very-low-density lipoprotein secretion. Biochemical Journal 310, 11-14.

Gibbons GF (1990) Assembly and secretion of hepatic very-lowdensity lipoprotein. Biochemical Journal 268, 1-13.

Gibbons GF \& Wiggins D (1995) Intracellular triacylglycerol lipase: its role in the assembly of hepatic very-low-density lipoprotein (VLDL). Advances in Enzyme Regulation 35, 179198.

Graulet B, Gruffat D, Durand D \& Bauchart D (1998) Fatty acid metabolism and very low density lipoprotein secretion in liver slices from rats and preruminant calves. Journal of Biochemistry 124, 1212-1219.

Graulet B, Gruffat-Mouty D, Durand D \& Bauchart D (2000) Effects of milk diets containing beef tallow or coconut oil on the fatty acid metabolism of liver slices from preruminant calves. British Journal of Nutrition 84, 309-318.

Gruffat D, Durand D, Chilliard Y, Williams P \& Bauchart D (1996a) Hepatic gene expression of apolipoprotein B100 during early lactation in underfed, high producing dairy cows. Journal of Dairy Science 80, 657-666.

Gruffat D, Durand D, Graulet B \& Bauchart D (1996b) Regulation of VLDL synthesis and secretion in the liver. Reproduction Nutrition Développement 36, 375-389.

Gruffat-Mouty D, Graulet B, Durand D, Samson-Bouma ME \& Bauchart D (1999) Apolipoprotein B production and very low density lipoprotein secretion by calf liver slices. Journal of Biochemistry 126, 188-193.

Grummer RR (1993) Etiology of lipid-related metabolic disorders in periparturient dairy cows. Journal of Dairy Science 76, $3882-3896$
Jenkins KJ \& Kramer JKG (1986) Influence of low linolenic acid in milk replacer on calf performance and lipids in blood plasma, heart and liver. Journal of Dairy Science 69, 1374-1386.

Jenkins KJ, Kramer JKG \& Sauer FD (1985) Influence of triglycerides and free fatty acids in milk replacers on calf performance, blood plasma and adipose lipids. Journal of Dairy Science 68, 669-675.

Khosla P \& Hayes KC (1993) Dietary palmitic acid raises plasma LDL cholesterol relative to oleic acid only at a high intake of cholesterol. Biochemica et Biophysica Acta 1210, 13-22.

Labarca C \& Paigen K (1980) A simple, rapid and sensitive DNA assay procedure. Analytical Biochemistry 102, 344-352.

Lehner R, Cui Z \& Vance E (1999) Subcellular localisation, developmental expression and characterisation of a liver triacylglycerol hydrolase. Biochemical Journal 338, 761-768.

Lehner R \& Verger R (1997) Purification and characterisation of a porcine microsomal triacylglycerol hydrolase. Biochemistry $\mathbf{3 6}$, 1861-1868.

Leplaix-Charlat L, Bauchart D, Durand D, Laplaud PM \& Chapman MJ (1996a) Plasma lipoproteins in preruminant calves fed diets containing tallow or soybean oil with and without cholesterol. Journal of Dairy Science 79, 12671277.

Leplaix-Charlat L, Durand D \& Bauchart D (1996b) Effects of diets containing tallow and soybean oil with and without cholesterol on hepatic metabolism of lipids and lipoproteins in the preruminant calf. Journal of Dairy Science 79, 18261835.

Marcos E, Mazur A, Cardot P \& Rayssiguier Y (1990) The effect of pregnancy and lactation on serum lipid and apolipoprotein B and A-I levels in dairy cows. Journal of Animal Physiology and Animal Nutrition 64, 133-138.

Petit D, Raisonnier A, Amit N \& Infante R (1982) Lack of induction of VLDL apoprotein synthesis by medium chain fatty acids in the isolated rat liver. Annals in Nutrition and Metabolism 26, 279-286.

Reid IM \& Collins RA (1980) The pathology of postparturient fatty liver in high-yielding dairy cows. Investigation in Cell Pathology 3, 237-249.

Sober HA (1970) Handbook of Biochemistry. Selected Data of Molecular Biology, 2nd ed., Cleveland, OH: The Chemical Rubber Co.

Toullec R (1978) Le Veau (The Calf). In Alimentation des Ruminants (Nutrition of Ruminants), pp. 245-274. Versailles Institut National de la Recherche Agronomique.

Ushida E, Katoh N \& Takahashi K (1992) Induction of fatty liver in cows by ethionine administration and concomitant decreases of serum apolipoproteins B-100 and A-I concentrations. American Journal of Veterinary Research 53, 2035-2042.

Wetterau JR, Lin MCM \& Jamil H (1997) Microsomal triglyceride transfer protein. Biochimica et Biophysica Acta 1345, 136-150.

Yang LY, Kuksis A, Myher JJ \& Steiner G (1995) Origin of triacylglycerol moiety of plasma very low density lipoproteins in the rat: structural studies. Journal of Lipid Research 36, $125-136$

Yao Z, Tran K \& McLeod RS (1997) Intracellular degradation of newly synthesized apolipoprotein B. Journal of Lipid Research 38, 1937-1953.

Yasuhara M, Ohama T, Matsuki N, Saito H, Matsushima T, Kurokawa K \& Teramoto BT (1991) Deficiency of apolipoprotein B synthesis in Suncus murinus. Journal of Biochemistry 110, 751-755. 